\title{
Systemic Administration of Calea pinnatifida Inhibits Inflammation Induced by Carrageenan in a Murine Model of Pulmonary Neutrophilia
}

\author{
Bruno Matheus de Campos Facchin, ${ }^{1}$ Julia Salvan da Rosa, ${ }^{1}$ Ana Beatriz Gobbo Luz, \\ Yeo Jim Kinoshita Moon, ${ }^{1}$ Tamires Cardoso de Lima, ${ }^{2}$ Rosana Casoti, ${ }^{3}$ \\ Maique Weber Biavatti, ${ }^{2}$ Eduardo Monguilhott Dalmarco $\mathbb{B D}^{1},{ }^{1}$ and Tânia Silvia Fröde ${ }^{1}$ \\ ${ }^{1}$ Department of Clinical Analysis, Center of Health Sciences, Federal University of Santa Catarina, Campus Universitário, Trindade, \\ Florianópolis, 88040-970 SC-, Brazil \\ ${ }^{2}$ Department of Pharmaceutical Sciences, Center of Health Sciences, Federal University of Santa Catarina, Campus Universitário, \\ Trindade, Florianópolis, 88040-970 SC-, Brazil \\ ${ }^{3}$ Department of Pharmaceutical Sciences, University of São Paulo, Ribeirão Preto, SP-, Brazil
}

Correspondence should be addressed to Eduardo Monguilhott Dalmarco; eduardo.dalmarco@ufsc.br

Received 8 November 2019; Accepted 4 January 2020; Published 25 January 2020

Academic Editor: Carla Sipert

Copyright (C) 2020 Bruno Matheus de Campos Facchin et al. This is an open access article distributed under the Creative Commons Attribution License, which permits unrestricted use, distribution, and reproduction in any medium, provided the original work is properly cited.

\begin{abstract}
Objective. The aim of this study was to investigate the anti-inflammatory effects of the crude extract (CE), derived fraction, and isolated compounds from Calea pinnatifida leaves in a mouse model of pulmonary neutrophilia. Methods. The CE and derived fractions, hexane, ethyl acetate, and methanol, were obtained from C. pinnatifida leaves. The compounds 3,5- and 4,5-di-O-Ecaffeoylquinic acids were isolated from the EtOAc fraction using chromatography and were identified using infrared spectroscopic data and nuclear magnetic resonance $\left({ }^{1} \mathrm{H}\right.$ and ${ }^{13} \mathrm{C}$ NMR). Leukocytes count, protein concentration of the exudate, myeloperoxidase (MPO) and adenosine deaminase (ADA), and nitrate/nitrite $\left(\mathrm{NO}_{x}\right)$, tumor necrosis factor-alpha (TNF- $\alpha$ ), interleukin-1-beta (IL-1 $\beta$ ), and interleukin-17A (IL-17A) levels were determined in the pleural fluid leakage after $4 \mathrm{~h}$ of pleurisy induction. We also analyzed the effects of isolated compounds on the phosphorylation of both p65 and p38 in the lung tissue. Results. The CE, its fractions, and isolated compounds inhibited leukocyte activation, protein concentration of the exudate, and MPO, ADA, $\mathrm{NO}_{x}$, TNF- $\alpha$, IL-1 $\beta$, and IL-17A levels. 3,5- and 4,5-di-O-E-caffeoylquinic acids also inhibited phosphorylation of both p65 and p38 $(P<0.05)$. Conclusion. This study demonstrated that $C$. pinnatifida presents important anti-inflammatory properties by inhibiting activated leukocytes and protein concentration of the exudate. These effects were related to the inhibition of proinflammatory mediators. The dicaffeoylquinic acids may be partially responsible for these anti-inflammatory properties through the inhibition of nuclear transcription factor kappa B and mitogen-activated protein kinase pathways.
\end{abstract}

\section{Introduction}

A variety of global diseases are related to nonresolving inflammation. Nonresolution of inflammatory processes is the main cause of many chronic inflammatory diseases, such as atherosclerosis, inflammatory bowel disease, rheumatoid arthritis, chronic obstructive pulmonary disease, and asthma [1]. Asthma is a chronic inflammatory disease characterized by airway hyperresponsiveness and reversible airway obstruction [2]. The mechanisms of eosinophilic inflammation in asthma have extensively been studied; however, little is known regarding noneosinophilic asthma and its development [3]. Recent studies have shown that approximately half of all asthma cases do not exhibit any evidence of eosinophilic inflammation and that some of these individuals present airway neutrophilia [4]. Airway neutrophilia is directly related to the severity of asthma and the refractory treatment for corticosteroids. However, 
the underlying mechanisms of airway neutrophilia are not well understood but appear to involve the activation and continuous flow of neutrophils [5].

A simple and reproducible experimental model is a basic requirement to evaluate the anti-inflammatory properties of plants used in traditional medicine. Carrageenan- (Cg-) induced inflammation is a commonly used model of local acute inflammation to evaluate the anti-inflammatory action of herbs and to assess the participation of cells and mediators in the inflammatory process. Also, Cg promotes a leukocyte influx due to neutrophils into the mouse pleural cavity $4 \mathrm{~h}$ after pleurisy induction [6]. This response is useful to study neutrophilia airway inflammation diseases such as asthma.

Therefore, the search for new therapeutics and bioactive compounds that may be effective in treating patients who do not respond to conventional asthma therapies is necessary. Research based on ethnopharmacological studies can assist in the selection of species with potential biological activities, thus contributing to new drug discoveries [7]. The Brazilian flora presents rich biodiversity, comprising $>50,000$ plant species, thus becoming an important source of medicinal plants and bioactive compounds. Moreover, the interest in medicinal plant properties has extensively been studied by Brazilian researchers because of the traditional use of medicinal plants in folk Brazilian medicine for various diseases, including inflammatory diseases [8-10].

The genus Calea belongs to the Asteraceae family and contains approximately 125 species distributed in tropical and subtropical areas worldwide, with the greatest number of species recorded in Brazil [11]. Studies of Calea species demonstrate important pharmacological properties, such as antihypertensive, vasodilator, antiparasitic, hypoglycemic, and anti-inflammatory effects [12-17]. Calea pinnatifida, popularly known as "aruca" and "cipó-cruz," is a perennial and subshrub plant found in Southern Brazil, and has been used in folk medicine to treat giardiasis and amoebiasis [18]. Although this species was not extensively studied thus far, recent studies have shown potential antiproliferative [19] and leishmanicidal effects [20]. The phytochemical profile of $C$. pinnatifida has revealed the presence of fatty esters, sterols, monoterpenes, sesquiterpene lactones, germacranolides, and phenolic acids [21, 22].

Regarding this last class of compounds, the derived caffeoylquinic acids appear to have important antiinflammatory actions and inhibit the nuclear transcription factor kappa B (NF- $\kappa \mathrm{B})$ pathway, an important intracellular signaling route responsible for the expression of proinflammatory genes involved in the development and progression of many inflammatory diseases, including asthma [23-26]. The anti-inflammatory activity of a mixture containing dicaffeoylquinic acids (diCQAs) has been tested in our research group, which have also demonstrated inhibitory effects on p65 NF- $\kappa$ B phosphorylation [27].

Considering the use of the Calea genre in inflammatory diseases and as treatment in folk medicine and the absence of studies confirming these biological effects, we aimed to study the anti-inflammatory actions of C. pinnatifida and elucidate its possible anti-inflammatory mechanisms using a murine model of pulmonary neutrophilia. Thus, we evaluated the effects of $C$. pinnatifida crude extract (CE), derived fractions, and isolated compounds (3,5-di-O-E-caffeoylquinic acid (3,5-diCQA), 4,5-di-O-E-caffeoylquinic acid (4,5-diCQA), and 3,4-di-O-E-caffeoylquinic acid (3,4-diCQA)) on leukocyte migration, protein concentration of the exudate, myeloperoxidase (MPO) and adenosine deaminase (ADA) activities, and nitric oxide metabolites $\left(\mathrm{NO}_{x}\right)$, tumor necrosis factor-alpha (TNF- $\left.\alpha\right)$, interleukin-1beta (IL-1 $\beta$ ), and interleukin-17A (IL-17A) levels. We also evaluated the ability of isolated $C$. pinnatifida compounds on the inhibition of important inflammatory pathways signal via p65 NF- $\kappa \mathrm{B}$ and p38 mitogen-activated protein kinases (MAPK) phosphorylation.

\section{Materials and Methods}

2.1. Collection and Extraction of Plant Material and Isolation and Identification of the Chemical Constituents. The methods used for the collection and extraction of plant material as well as for the isolation and identification of the chemical constituents were performed as previously described by Lima et al. [28]. C. pinnatifida leaves were collected in June 2013 from Costa da Lagoa, Florianópolis, Brazil. Botanical identification was provided by Dr. John F. Pruski, New York Botanical Garden, and a voucher specimen has been maintained at the Missouri Botanical Garden Herbarium, St. Louis, Missouri, USA (No: MO-2383318). Fresh leaves of $C$. pinnatifida $(2.6 \mathrm{~kg})$ were subjected to exhaustive extraction by maceration with $92 \%$ ethanol for 15 days at approximately $25^{\circ} \mathrm{C}$. The solvent was removed under reduced pressure on a rotatory evaporator yielding $142.0 \mathrm{~g}$ of CE. The CE was suspended in $\mathrm{H}_{2} \mathrm{O}$ and partitioned using $n$-hexane $(n$-Hex), followed by dichloromethane (DCM) and ethyl acetate (EtOAc), resulting in three fractions: (1) Hex, 68.5 g; (2) DCM, $7.6 \mathrm{~g}$; and (3) EtOAc, $5.9 \mathrm{~g}$. The remaining aqueous fraction $(60.0 \mathrm{~g})$ was subjected to column chromatography (CC) using Amberlite XAD-4 resin as the stationary phase and methanol $(\mathrm{MeOH})$ as the mobile phase, resulting in a $\mathrm{MeOH}$ fraction $(28.3 \mathrm{~g}$ ). Subsequently, an aliquot of EtOAc fraction $(4.9 \mathrm{~g})$ was further fractionated using vacuum liquid chromatography (VLC) on silica gel and eluted with $\mathrm{CH}_{2} \mathrm{Cl}_{2}$, EtOAc, and $\mathrm{MeOH}$ in mixtures of increasing polarity to yield eight subfractions, (A-H). Subfraction C (126.5 mg) was purified using medium-pressure liquid chromatography on a reverse-phase (RP-18) column using a gradient solvent system of $\mathrm{H}_{2} \mathrm{O}-\mathrm{MeOH}(95: 5 \rightarrow 0: 100)$ as mobile phase to yield 73 fractions. Fractions F50-53 eluted with $\mathrm{H}_{2} \mathrm{O}-\mathrm{MeOH}$ (60:40) provided $22.7 \mathrm{mg}$ of compound 2. Finally, an $800.0 \mathrm{mg}$ aliquot of subfraction $\mathrm{E}$ was chromatographed over a Sephadex LH-20 column using acetone-MeOH $(1: 1)$ as a solvent to obtain 37 fractions. Based on the thin layer chromatography (TLC) profile, collected fractions were combined, and an aliquot of the fractions F16-19 (60 mg) was further purified using preparative high-performance liquid chromatography (HPLC) to yield 6.4 and $10.3 \mathrm{mg}$ of compounds 1 and 3 , respectively. Chromatography was performed with isocratic elution, a flow rate of $1.5 \mathrm{~mL} / \mathrm{min}$, injection volume of $1000 \mu \mathrm{L}$, and $\mathrm{ACN}-\mathrm{H}_{2} \mathrm{O}$ as mobile phase 
$(20: 80, v / v)$, containing $1 \%$ formic acid; ultraviolet (UV) detection was at $325 \mathrm{~nm}$.

\subsection{Ultra-High-Pressure Liquid Chromatography-DAD-} High-Resolution Electrospray Ionization Mass Spectrometry Conditions. Ultra-high-pressure liquid chromatography (UHPLC) analyses were performed using a C18 reversephase column $\mathrm{ACE}^{\circledR}(3 \mu \mathrm{m}$ particle size, $150 \times 3 \mathrm{~mm})$ at $30^{\circ} \mathrm{C}$ with gradient elution at a flow rate of $0.4 \mathrm{~mL} / \mathrm{min}$. The injection volume was $5 \mu \mathrm{L}$ at concentrations of $0.5 \mathrm{mg} / \mathrm{mL}$ of extract/organic fractions in $70 \% \mathrm{EtOH}$, and the analysis time was $30 \mathrm{~min}$. The mobile phase eluents consisted of solvents $\mathrm{A}\left(\mathrm{H}_{2} \mathrm{O}\right)$ and $\mathrm{B}$ (acetonitrile $(\mathrm{ACN})$ ), both containing $0.1 \%$ formic acid. The mobile phase was programmed in a linear gradient as follows: $0-17 \mathrm{~min}, 2 \%-55 \% \mathrm{~B} ; 17-20 \mathrm{~min}$, $55 \%-100 \% \mathrm{~B}$; $24-27 \mathrm{~min}, 100 \%-2 \% \mathrm{~B}$; and $27-30 \mathrm{~min}, 2 \%$ B. UV detection was conducted at 214,254 , and $325 \mathrm{~nm}$.

Mass spectra were concurrently acquired in both positive and negative modes, with a mass range of $150-1200 \mathrm{~m} / z$. Several parameters were used for all analyses: fragmentation HCD gas off; resolution, 70,000; maximum injection time, $200 \mathrm{~ms}$; capillary temperature, $300^{\circ} \mathrm{C}$; AGC target, $3 \mathrm{e} 6$; microscans, $1 \mathrm{~s}$; and spray voltage, $3.6 \mathrm{kV}$.

2.3. General Experimental Procedures. Proton nuclear magnetic resonance $\left({ }^{1} \mathrm{H}\right.$ NMR) spectra and correlation maps (HSQC and HMBC) were recorded using a Bruker Ascend 600 spectrometer, operating at $600 \mathrm{MHz}$ for ${ }^{1} \mathrm{H}$ and $150 \mathrm{MHz}$ for ${ }^{13} \mathrm{C}$. NMR experiments were conducted in $\mathrm{MeOH}-d_{4}$ containing a few drops of TMS (0.00 ppm, internal standard), and the data were analyzed utilizing the ACD/labs NMR software. Chemical shifts $(\delta)$ and coupling constants $(J)$ were expressed in ppm and in hertz $(\mathrm{Hz})$, respectively. Highresolution electrospray ionization mass spectrometry (HRESIMS) data were measured on an Accela ${ }^{\mathrm{TM}}$ UHPLC equipped with an UV-DAD detector and an Exactive ${ }^{\mathrm{TM}}$ Plus Orbitrap mass spectrometer (Thermo Fisher Scientific) using an electrospray ionization source. Data were acquired and processed using the Xcalibur ${ }^{\mathrm{TM}}$ software (Thermo Fisher Scientific). Preparative HPLC analyses were performed using a Shimadzu HPLC system (Kyoto, Japan) consisting of a SCL-10ADVP system controller, two LC-10 AD pumps, a SPD-10AV UV detector, and a manual injection system. HPLC analyses were conducted on a C18 reverse-phase column Luna type $\left(10 \mu \mathrm{m}, 250 \times 10 \mathrm{~mm}\right.$, Phenomenex $\left.{ }^{\circledR}\right)$. Silica gel $60 \mathrm{~F}_{254}$ $(0.04-0.63 \mu \mathrm{m}, 240-400 \mathrm{mesh})$ utilized for VLC, and CC was acquired from Vetec, Brazil; analytical TLC was obtained from Silicycle; Sephadex LH-20 was purchased from Tedia Brazil; and Amberlite XAD-4 was acquired from Supelco (Sigma Aldrich, Pte. Ltd., Singapore). HPLC grade ACN was acquired from Dist (Florianópolis, SC, Brazil).

2.4. Animals. For the experiments, female Swiss mice, weighing between 18 and $22 \mathrm{~g}$, were used. The animals received food and water ad libitum and were housed under controlled light $(12 \mathrm{~h} \mathrm{light/dark}$ cycle $)$ and temperature $\left(20 \pm 2^{\circ} \mathrm{C}\right)$. All procedures performed in this study were in accordance with the ethical standards of the institution or practice in which the studies were conducted. In this study minimum number of animals were used to be consistent the statistical analysis. This protocol was approved by the ethics committee for Animal Research at Federal University of Santa Catarina (CEUA-Protocol PP00757/CEUA/2012).

2.5. Carrageenan-Induced Pleurisy. Pleurisy was induced by an injection of $0.1 \mathrm{~mL}$ carrageenan $(\mathrm{Cg}, 1 \%)$ according to previously described methods [6]. After $4 \mathrm{~h}$, the mice were sacrificed, and the pleural cavity was exposed and washed with $1.0 \mathrm{~mL}$ heparinized $(20 \mathrm{UI} / \mathrm{mL})$ phosphate-buffered saline ( $\mathrm{pH}$ 7.6). The pleural samples from different groups of mice were used to quantify leukocytes, protein concentration of the exudate, MPO and ADA activities, $\mathrm{NO}_{x}$ levels, and cytokine levels (TNF- $\alpha$, IL-17A, and IL-1 $\beta$ ). The lung tissues were collected to evaluate the effects of the isolated compounds on p65 NF- $\kappa \mathrm{B}$ and p38 MAPK phosphorylation.

2.6. Experimental Protocol. For dosages used in animals, the analysis of the dose-response curve was performed. In this protocol, different groups of mice were treated with different doses of CE $(25-100 \mathrm{mg} / \mathrm{kg}$ ), derived fractions (Hex, 5$25 \mathrm{mg} / \mathrm{kg}$; $\mathrm{MeOH}, 5-25 \mathrm{mg} / \mathrm{kg}$; and EtOAc, $2.5-25 \mathrm{mg} / \mathrm{kg}$ ), and isolated compounds (3,5-diCQA, $1-5 \mathrm{mg} / \mathrm{kg} ; 4,5-$ diCQA, $1-5 \mathrm{mg} / \mathrm{kg}$; and 3,4-diCQA, $1-5 \mathrm{mg} / \mathrm{kg}$ ) administered via the intraperitoneal route (i.p.) $0.5 \mathrm{~h}$ before pleurisy induction. The inflammatory parameters, exudate protein concentration, and leukocyte activation were evaluated after $4 \mathrm{~h}$.

To evaluate the time course profiles, the lower dose of $\mathrm{CE}$ that caused the most significant inhibition of leukocyte activation and protein concentration of the exudate was selected. In this protocol, different groups of animals were treated with $50 \mathrm{mg} / \mathrm{kg}$ of $\mathrm{CE} 0.5,1,2$, and $4 \mathrm{~h}$ before $\mathrm{Cg}$ injection. Inflammatory parameters were analyzed $4 \mathrm{~h}$ after pleurisy induction. The time course profile of $\mathrm{CE}$ $(50 \mathrm{mg} / \mathrm{kg})$ indicated that the anti-inflammatory activity on leukocyte activation and exudate protein concentration occurred when $\mathrm{CE}$ was administered $0.5 \mathrm{~h}$ before the pleurisy induction (results not shown). The results of the time course profiles obtained with CE were extended to the fractions and isolated compounds.

Based on the results obtained in the abovementioned protocols, we selected the single doses of CE $(50 \mathrm{mg} / \mathrm{kg})$, fractions (Hex, $10 \mathrm{mg} / \mathrm{kg} ; \mathrm{MeOH}, 10 \mathrm{mg} / \mathrm{kg}$; and EtOAc, $5 \mathrm{mg} / \mathrm{kg}$ ), and isolated compounds (3,5-diCQA, $2.5 \mathrm{mg} / \mathrm{kg}$ and $4,5-\mathrm{diCQA}, 5 \mathrm{mg} / \mathrm{kg}$ ); these were all administered $0.5 \mathrm{~h}$ before Cg-induced pleurisy and were used to evaluate other inflammatory parameters. The inflammatory parameters were also analyzed $4 \mathrm{~h}$ after pleurisy induction.

A group of animals was concomitantly challenged only with $\mathrm{Cg}(1 \%)$ and was considered the positive control group, whereas the negative control group received only sterile saline $(0.95 \% \mathrm{NaCl})$; both groups were administered via i.p. Dexamethasone (Dex, $0.5 \mathrm{mg} / \mathrm{kg}$, i.p.) and indomethacin (Indo, $5 \mathrm{mg} / \mathrm{kg}$, i.p.) were administered in different groups of animals as anti-inflammatory reference drugs in all experimental procedures. 
2.7. Quantification of Leukocytes and Exudate Protein Concentration. After sacrificing the animals with pentobarbital overdose $(180 \mathrm{mg} / \mathrm{kg})$, fluid leakage from the mouse pleural cavity was collected for measuring the total and differential leukocytes count and protein concentration of the exudate. The total leukocyte count was performed using a veterinarian automatic counter (MINDRAY, BC-2800 Vet, Nanshan, Shenzhen, China). For differential leukocytes count, $50 \mu \mathrm{L}$ aliquots were centrifuged in cytospin (Cytopro ${ }^{\circledR}$ Cytocentrifuge Wescor, Model: 7620 USA) and stained using the May Grunwald-Giemsa method. The differential cell count was determined using an optical microscope with an oil immersion objective $(1000 \times)$. The results are expressed as relative fold change in relation to saline group.

The exudate protein concentration was measured by amount of Evans blue present in the fluid leakage from the mouse pleural cavity. In this protocol, a group of animals received an intravenous injection of Evans blue solution $(25 \mathrm{mg} / \mathrm{kg}) 0.5 \mathrm{~h}$ before the induction of pleurisy. The exudate protein concentration were determined by interpolation from a standard curve of Evans blue $(0.01-50 \mu \mathrm{g} / \mathrm{mL})$ by colorimetric measurements $(620 \mathrm{~nm})$ in an enzyme-linked immunosorbent assay (ELISA) plate reader (Organon Teknika, Roseland, NJ, USA). The results are expressed in $\mu \mathrm{g} / \mathrm{mL}$.

2.8. Quantification of MPO and ADA Levels. The analysis of MPO and ADA levels were performed according to previously described methods $[29,30]$.

For the determination of MPO activity, $100 \mu \mathrm{L}$ samples of fluid leakage from the mouse pleural cavity were treated with hexadecyltrimethylammonium bromide $(0.5 \%)$, and this mixture was frozen and thawed for three cycles. Subsequently, the samples were centrifuged at $40,000 \mathrm{~g}$ for $15 \mathrm{~min}$ at $4^{\circ} \mathrm{C}$. In total, $20 \mu \mathrm{L}$ of each of the sample supernatants were added to $180 \mu \mathrm{L}$ of the reagent solution $(0.167 \mathrm{mg} / \mathrm{mL}$ o-dianisidine. $2 \mathrm{HCl}$ and $0.0005 \% \mathrm{H}_{2} \mathrm{O}_{2}$ ), transferred to the enzyme immunoassay plates, and incubated at $37^{\circ} \mathrm{C}$ for $15 \mathrm{~min}$. The enzymatic reaction was stopped by adding $15 \mu \mathrm{L}$ sodium azide (1\%). Following a $10 \mathrm{~min}$ incubation at $37^{\circ} \mathrm{C}$, the enzymatic activity was determined by interpolation from a standard MPO curve $(0.7-140 \mathrm{mU} / \mathrm{mL})$ by colorimetric measurements $(450 \mathrm{~nm})$ in an ELISA plate reader (Organon Teknika, Roseland, NJ, USA). The results are expressed in $\mathrm{mU} / \mathrm{mL}$.

For quantification of ADA activity, fluid leakage samples from the mouse pleural cavity containing the enzyme were transferred to test tubes, and the reaction was started by adding $250 \mu \mathrm{L}$ of a buffered adenosine solution $(21 \mathrm{nM}$ adenosine, $35 \mathrm{mM} \quad \mathrm{NaH}_{2} \mathrm{PO}_{4} \cdot \mathrm{H}_{2} \mathrm{O}: 15 \mathrm{mM} \quad \mathrm{Na}_{2} \mathrm{HPO}_{4} \cdot 12 \mathrm{H}_{2} \mathrm{O}$, $\mathrm{pH}$ 6.5). After incubation for $60 \mathrm{~min}$ at $37^{\circ} \mathrm{C}, 500 \mu \mathrm{L}$ of a phenol/sodium nitroprusside solution $\left(106 \mathrm{nM} \mathrm{C}_{6} \mathrm{H}_{5} \mathrm{OH}\right.$; $\left.0.17 \mathrm{nM} \mathrm{C}_{5} \mathrm{FeN}_{5} \mathrm{Na}_{2} \mathrm{O} \cdot 2 \mathrm{H}_{2} \mathrm{O}\right)$ and $500 \mu \mathrm{L}$ of an alkaline sodium hypochlorite solution ( $11 \mathrm{nM} \mathrm{NaOCl} ; 125 \mathrm{nM} \mathrm{NaOH}$ ) were added to each sample and incubated at $37^{\circ} \mathrm{C}$ for $30 \mathrm{~min}$. Subsequently, the enzymatic activity was determined by interpolation from a standard ADA curve $(10-50 \mathrm{U} / \mathrm{L})$ by colorimetric measurements $(630 \mathrm{~nm})$ in an ELISA plate reader (Organon Teknika, Roseland, NJ, USA). The results are expressed in U/L.
2.9. Quantification of NO Metabolites $\left(\mathrm{NO}_{x}\right)$ Levels. Quantification of the NO products in the fluid leakage from mouse pleural cavities was performed according to previously described methods [31].

Fluid samples $(100 \mu \mathrm{L})$ were transferred to cuvettes, and $0.05 \mathrm{M}$ vanadium chloride $(150 \mu \mathrm{L})$ in $1.0 \mathrm{M} \mathrm{HCl}(50 \mu \mathrm{L})$ was added to reduce nitrate to nitrite. Griess reagent ( $300 \mu \mathrm{L} ; 0.004 \mathrm{M}$ naphthyl ethylenediamine dihydrochloride in $\mathrm{H}_{2} \mathrm{O}$ and $0.06 \mathrm{M}$ sulfanilamide in $0.03 \mathrm{M} \mathrm{H}_{3} \mathrm{PO}_{4}, 1: 1 \mathrm{v} / \mathrm{v}$ ) was then immediately added. After incubation at $37^{\circ} \mathrm{C}$ for $45 \mathrm{~min}$, the reaction was transferred to an ELISA microplate. Nitrite levels were estimated by interpolation from a standard curve of sodium nitrite $(0-150 \mu \mathrm{M})$ by colorimetric measurements $(540 \mathrm{~nm})$ in an ELISA plate reader (Organon Tecknika, Roseland, NJ, USA). The results are expressed in $\mu \mathrm{M}$.

2.10. Quantification of TNF- $\alpha, I L-17 A$, and IL-1 $\beta$ Levels. TNF- $\alpha$, IL-1 $\beta$, and IL-17A levels in the fluid leakage from the mouse pleural cavity were determined using commercial kits containing monoclonal antibodies for each cytokine. The analyses were performed using ELISA, according to the manufacturer's instructions (TNF- $\alpha$, eBioscience, Inc., San Diego, CA, USA, Cat 88-7342-29; IL-17A, eBioscience, Inc., San Diego, CA, USA, Cat 887971-29; IL-1 $\beta$, eBioscience, Inc., San Diego CA, USA, Cat 88-7913-29). The intra- and interassay coefficients of variation (CV) for TNF- $\alpha$, IL- $1 \beta$, and IL-17A were as follows: (1) intra-CV for TNF- $\alpha=7.87 \pm 0.9 \%$, IL- $1 \beta=$ $6.27 \pm 0.4 \%$, and IL- $17 \mathrm{~A}=7.57 \pm 1.7 \%$ and $(2)$ inter-CV for TNF- $\alpha=9.67 \pm 2.1 \%$, IL- $1 \beta=5.17 \pm 0.6 \%$, and IL- $17 \mathrm{~A}=$ $9.67 \pm 2.1 \%$; with sensitivity values of TNF- $\alpha=5.0 \mathrm{pg} / \mathrm{mL}$, IL- $1 \beta=1.7 \mathrm{pg} / \mathrm{mL}$, and IL- $17 \mathrm{~A}=4.0 \mathrm{pg} / \mathrm{mL}$. The quantifications were made by interpolation from a standard curve for each cytokine studied by colorimetric measurements $(450 \mathrm{~nm})$ in an ELISA plate reader (Organon Teknika, Roseland, NJ, USA). The results are expressed in $\mathrm{pg} / \mathrm{mL}$.

2.11. Quantification of Proteins. Following the experimental procedures, $20 \mathrm{mg}$ of lung tissue from each animal were removed from the thoracic cavity and transferred to Eppendorf tubes containing lysis buffer, Cell Lysis Buffer 5X (eBioscience, San Diego, CA), to form the homogenate.

The total protein dose was determined as previously reported [32]. Samples $(5 \mu \mathrm{L})$ from the lung tissue were added to $95 \mu \mathrm{L}$ distilled water plus $100 \mu \mathrm{L}$ Lowry reagent (25\% copper-tartrate-carbonate, $25 \%$ sodium dodecyl sulfate $10 \%, 20 \% 0.8 \mathrm{~N} \mathrm{NaOH}, 30 \%$ distilled water). After incubation at room temperature for $10 \mathrm{~min}, 50 \mu \mathrm{L}$ of Folin reagent $(40 \%$ $1 \mathrm{~N}$ reactive Folin, 20\% $2 \mathrm{~N}$ reactive Folin, and 40\% distilled water) was added to the mixture and then incubated for $30 \mathrm{~min}$. After this period, the mixture was pipetted into $96-$ well plates, and the total protein quantification was made by interpolation from a standard curve $(0-40 \mu \mathrm{g} / \mu \mathrm{L})$ by colorimetric measurements $(630 \mathrm{~nm})$ in an ELISA plate reader (Organon Teknika, Roseland, NJ, USA).

As suggested by the manufacturer, this procedure was performed to adjust the concentrations of each 


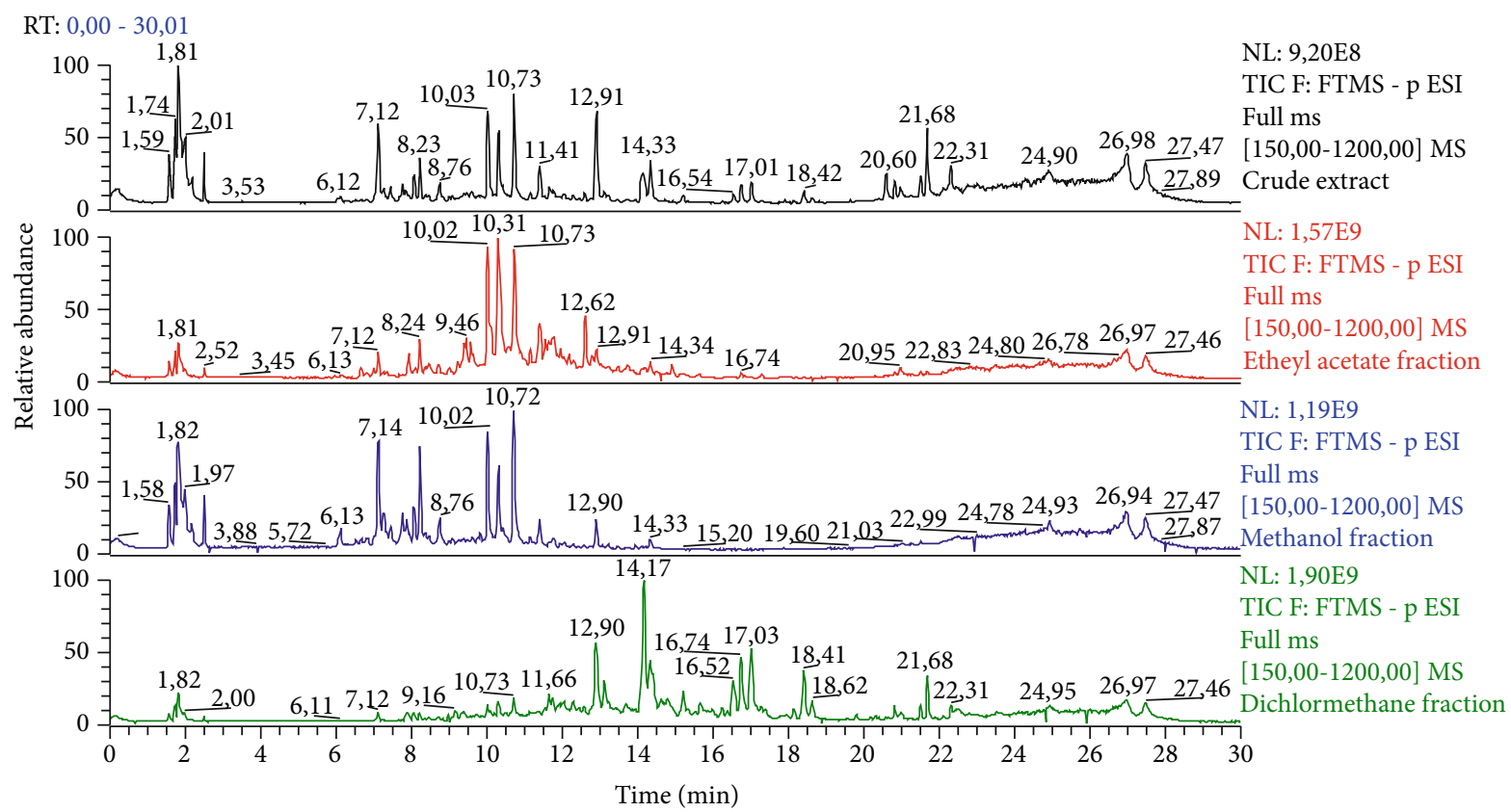

FIGURE 1: High-resolution electrospray ionization mass spectrometry (HRESIMS) total-ion chromatograms in the negative ion mode of crude extract and ethyl acetate, methanol and dichloromethane fractions. The compounds 3,4-diCQA (1), 3,5-diCQA (2), and 4,5-diCQA (3) possess retention time of $10.0,10.31$, and $10.73 \mathrm{~min}$, respectively.

sample to $60 \mu \mathrm{g}$ protein/sample for determining protein phosphorylation.

2.12. Quantification of $p 65 N F-\kappa B$ Phosphorylation. For this protocol, a commercial kit containing monoclonal antibodies specific to phosphorylated mouse p65 protein (phosphop65 NF- $\kappa \mathrm{B}$ (Ser536) Instant One ELISA kit, eBioscience, San Diego, California, USA) were used. The experimental protocol was performed according to the manufacturer's instructions. Colorimetric measurements ( $450 \mathrm{~nm}$ ) were performed on an ELISA plate reader, and results are expressed as relative fold change compared with the negative control group, which represent the basal expression of phosphorylated $\mathrm{p} 65 \mathrm{NF}-\kappa \mathrm{B}$.

2.13. Quantification of $p 38$ MAPK Phosphorylation. Samples of fluid leakage from mouse pleural cavities were adjusted using the Lowry method to contain the same protein concentrations $(60 \mu \mathrm{g})$. The samples were transferred to a plate with microwells containing specific monoclonal antibodies against the phosphorylated protein p38 MAPK (phospho-p38 MAPK (Tyr180/Tyr182) Instant One ELISA kit, eBioscience, San Diego, California, USA $\backslash$ ). Colorimetric measurements $(450 \mathrm{~nm})$ were performed on an ELISA plate reader, and the results are expressed as relative fold change when compared with the negative control group; this was used to represent the basal expression of phosphorylated p38 MAPK.

2.14. Statistical Analysis. All data are expressed as mean \pm standard error of the mean and percent of inhibition. The significant differences between groups were determined using analysis of variance followed by Newman-Keuls post hoc test. The results were analyzed using GraphPad Prism v5.0 Software (GraphPad Software Inc., San Diego, California, USA), and $P$ values of $<0.05$ were considered significant.

\section{Results}

3.1. Phytochemical Analysis. Analysis of the chemical composition of C. pinnatifida extract and organic fractions (DCM, EtOAc, and $\mathrm{MeOH}$ ) using UHPLC-DAD-HRESIMS revealed the presence of several phenolic compounds (flavonoids, hydroxycinnamic acid derivatives, and chromenes). Based on the UV spectrum of the constituents with retention times $10.03,10.31$, and $10.73 \mathrm{~min}$, the presence of chlorogenic acid derivatives was suggested (Figure 1). LC-MS analyses in the negative ion mode using an ESI orbitrap mass spectrometer and the hierarchical key proposed by Clifford and coworkers [33-36] for discriminating between isomers of dicaffeoylquinic acid enabled us to conclude that these chlorogenic acid derivatives were compounds (1) 3,4diCQA, (2) 3,5-diCQA, and (3) 4,5-diCQA. The Hex fraction was not analyzed using UHPLC on reverse-phase column because nonpolar compounds may display high adsorption on this type of stationary phase.

Based on UHPLC analyses, the chromatographic separation of the EtOAc fraction led to the isolation and characterization of the three structural isomeric chlorogenic acid derivatives previously identified using UHPLC-DAD-HRESIMS: (1) 3,4-diCQA, (2) 3,5-diCQA, and (3) 4,5-diCQA. The compounds' structures were confirmed as described by Lima et al. [28]. Compound 2 was identified by comparing its $1 \mathrm{D}$ and $2 \mathrm{D}$ NMR spectroscopic data with those published in the literature by Lima et al. [37] and compounds 1 and 3 were distinguished based on their MS/MS 
TABLE 1: Effects of CE, fractions, and isolated compounds obtained from C. pinnatifida leaves upon relative fold change of leukocytes and exudate protein concentration in a murine model of carrageenan-induced pleurisy.

\begin{tabular}{|c|c|c|c|}
\hline Groups (mg/kg) & Relative fold change of leukocytes & Relative fold change of neutrophils & Exudate protein concentration $(\mu \mathrm{g} / \mathrm{mL})$ \\
\hline $\mathrm{Sal}^{\mathrm{a}}$ & - & - & $2.34 \pm 0.15$ \\
\hline $\mathrm{Cg}^{\mathrm{a}}$ & $5.11 \pm 0.31$ & $8.63 \pm 0.12$ & $16.00 \pm 0.85$ \\
\hline $\mathrm{CE}(25)^{\mathrm{b}}$ & $4.88 \pm 0.07$ & $8.09 \pm 0.20$ & $14.45 \pm 1.01$ \\
\hline $\mathrm{CE}(50)^{\mathrm{b}}$ & $3.01 \pm 0.0^{* *}$ & $4.85 \pm 0.17^{* *}$ & $12.75 \pm 0.71^{*}$ \\
\hline $\mathrm{CE}(100)^{\mathrm{b}}$ & $2.98 \pm 0.03^{* *}$ & $4.86 \pm 0.08^{* *}$ & $10.61 \pm 0.76^{* *}$ \\
\hline $\operatorname{Hex}(5)^{\mathrm{b}}$ & $4.88 \pm 0.09$ & $8.09 \pm 0.22$ & $15.20 \pm 1.85$ \\
\hline $\operatorname{Hex}(10)^{b}$ & $1.64 \pm 0.10^{* *}$ & $2.37 \pm 0.13^{* *}$ & $11.73 \pm 0.91^{* *}$ \\
\hline $\operatorname{Hex}(25)^{b}$ & $2.56 \pm 0.19^{* *}$ & $4.13 \pm 0.26^{* *}$ & $10.35 \pm 1.17^{* *}$ \\
\hline $\mathrm{MeOH}(5)^{\mathrm{b}}$ & $2.83 \pm 0.93^{* *}$ & $4.82 \pm 1.01^{* *}$ & $20.18 \pm 0.17$ \\
\hline $\mathrm{MeOH}(10)^{\mathrm{b}}$ & $2.46 \pm 0.19^{* *}$ & $4.13 \pm 0.21^{* *}$ & $11.32 \pm 0.85^{* *}$ \\
\hline $\mathrm{MeOH}(25)^{\mathrm{b}}$ & $2.69 \pm 0.27^{* *}$ & $4.58 \pm 0.29^{* *}$ & $11.97 \pm 1.03^{* *}$ \\
\hline EtOAc $(2.5)^{\mathrm{b}}$ & $4.79 \pm 0.16$ & $8.16 \pm 0.19$ & $15.72 \pm 0.65$ \\
\hline $\operatorname{EtOAc}(5)^{\mathrm{b}}$ & $1.85 \pm 0.08^{* *}$ & $2.82 \pm 0.31^{* *}$ & $8.83 \pm 0.35^{* *}$ \\
\hline $\operatorname{EtOAc}(10)^{\mathrm{b}}$ & $1.77 \pm 0.09^{* *}$ & $2.62 \pm 0.13^{* *}$ & $7.56 \pm 1.41^{* *}$ \\
\hline EtOAc $(25)^{\mathrm{b}}$ & $1.64 \pm 0.15^{* *}$ & $2.36 \pm 0.12^{* *}$ & $10.64 \pm 0.46^{* *}$ \\
\hline 3,5-diCQA $(1)^{\mathrm{b}}$ & $5.23 \pm 0.16$ & $8.47 \pm 0.09$ & $15.05 \pm 0.47$ \\
\hline 3,5-diCQA $(2.5)^{\mathrm{b}}$ & $3.69 \pm 0.21^{* *}$ & $6.14 \pm 0.19^{* *}$ & $10.91 \pm 0.80^{* *}$ \\
\hline $3,5-\operatorname{diCQA}(5)^{\mathrm{b}}$ & $3.21 \pm 0.22^{* *}$ & $4.91 \pm 0.26^{* *}$ & $10.08 \pm 0.75^{* *}$ \\
\hline 4,5 -diCQA $(1)^{\mathrm{b}}$ & $4.74 \pm 0.20$ & $8.09 \pm 0.12$ & $15.15 \pm 0.63$ \\
\hline 4,5 -diCQA $(2.5)^{\mathrm{b}}$ & $5.22 \pm 0.31$ & $8.82 \pm 0.31$ & $14.36 \pm 0.75$ \\
\hline $4,5-\operatorname{diCQA}(5)^{\mathrm{b}}$ & $3.00 \pm 0.19^{* *}$ & $4.83 \pm 0.47^{* *}$ & $7.21 \pm 0.80^{* *}$ \\
\hline $\operatorname{Dex}(0.5)^{\mathrm{b}}$ & $2.49 \pm 0.21^{* *}$ & $4.22 \pm 0.23^{* *}$ & $10.15 \pm 0.45^{* *}$ \\
\hline Indo $(5)^{\mathrm{b}}$ & $2.83 \pm 0.27^{* *}$ & $4.75 \pm 0.36^{* *}$ & $11.41 \pm 0.50^{* *}$ \\
\hline
\end{tabular}

Crude extract (CE: $25-100 \mathrm{mg} / \mathrm{kg}$ ), hexane fraction (Hex: 5-25 mg/kg), methanol fraction (MeOH: 5-25 mg/kg), ethyl acetate fraction (EtOAc: $2.5-25 \mathrm{mg} / \mathrm{kg}$ ), 3,5-di-O-E-caffeoylquinic acid (3,5-diCQA: $1-5 \mathrm{mg} / \mathrm{kg}$ ), and 4,5-di-O-E-caffeoylquinic acid (4,5-diCQA: 1-5 mg/kg) obtained from C. pinnatifida leaves administered $0.5 \mathrm{~h}$ before pleurisy induction. Sal: negative control group, animals treated only with sterile saline (0.95\%); Cg: positive control group, animals treated only with carrageenan (1\%); Dex: animals treated with dexamethasone $(0.5 \mathrm{mg} / \mathrm{kg}) 0.5 \mathrm{~h}$ before pleurisy induction; Indo: animals treated with indomethacin $(5 \mathrm{mg} / \mathrm{kg}) 0.5 \mathrm{~h}$ before pleurisy induction. ${ }^{\mathrm{a}}$ Administered by intrapleural route (i.pl.). ${ }^{\mathrm{b}}$ Administered by intraperitoneal route (i.p.). Each group represents the mean \pm SEM of six animals. ${ }^{*} P<0.05$ and ${ }^{* *} P<0.01$.

fragmentation patterns in MS experiments and in the hierarchical fragmentation scheme previously established by Clifford and coworkers [33-36] to characterize chlorogenic acid derivatives.

3.2. Effect of CE, Fractions, and Isolated Compounds of C. pinnatifida on Relative Fold Change of Leukocytes and Exudate Protein Concentration. Doses of 50 and $100 \mathrm{mg} / \mathrm{kg} \mathrm{CE}$ significantly inhibited leukocytes by $41.11 \pm 3.76 \%$ and $41.69 \pm 1.3 \%$, respectively $(P<0.01)$. This inhibition was associated with a significant decrease in the relative fold change of neutrophils by $42.13 \pm 0.99 \%$ and $42.13 \pm 2.99 \%$, respectively $(P<0.01)$. Moreover, at the same doses, $\mathrm{CE}$ inhibited exudate protein concentration by $20.25 \pm 4.49 \%$ and $33.62 \pm 4.76 \%$, respectively $(P<0.05)$ (Table 1$)$.

Doses of 10 and $25 \mathrm{mg} / \mathrm{kg}$ Hex fraction demonstrated a significant anti-inflammatory effect by decreasing the relative fold change of leukocytes by $48.19 \pm 2.96 \%$ and $65.78 \pm 1.38$ $\%$, respectively $(P<0.01)$; this effect was due to the reduction on relative fold change of neutrophils by $51.03 \pm 3.08 \%$ and
$71.32 \pm 1.09 \%$, respectively $(P<0.01)$. Moreover, the Hex fraction decreased the exudate protein concentration by $26.66 \pm 5.74 \%$ and $35.29 \pm 7.94 \%$, respectively $(P<0.01)$ (Table 1).

Doses of $5-25 \mathrm{mg} / \mathrm{kg} \mathrm{MeOH}$ fraction reduced the relative fold change of leucocytes ranging from $42.34 \pm 6.09 \%$ to $50.32 \pm 2.98 \%(P<0.01)$, and this inhibition was related to the decrease in relative fold change of neutrophils ranging from $42.31 \pm 15.87 \%$ to $51.54 \pm 4.61 \%(P<0.01)$ (Table 1$)$. However, only doses of 10 and $25 \mathrm{mg} / \mathrm{kg}$ of this fraction were effective in inhibiting the exudate protein concentration by $25.17 \pm 6.46 \%$ and $29.23 \pm 5.32 \%$, respectively $(P<0.01)$ (Table 1).

Similar to the $\mathrm{MeOH}$ fraction, 5-25 mg/kg EtOAc fraction was effective in reducing the relative fold change of leukocytes ranging from $62.23 \pm 3.42 \%$ to $66.23 \pm 1.94 \%(P<0.01)$, and this effect appeared to be related to the decrease in neutrophils ranging from $66.23 \pm 4.12 \%$ to $71.23 \pm 1.89 \% \quad(P<0.01)$. Moreover, the EtOAc fraction at three tested doses $(5,10$, and $25 \mathrm{mg} / \mathrm{kg}$ ) significantly decreased exudate protein 
concentration ranging from $33.49 \pm 2.91 \%$ to $52.69 \pm 8.83 \%$ $(P<0.01)$ (Table 1$)$.

The 3,5- and 4,5-diCQA isomers inhibited leukocytes (\% inhibition: 3,5-diCQA, $2.5 \mathrm{mg} / \mathrm{kg}: 27.78 \pm 4.87 \%$ and $5 \mathrm{mg} / \mathrm{kg}$ : $37.08 \pm 6.69 \%$; 4,5-diCQA, $5 \mathrm{mg} / \mathrm{kg}: 41.40 \pm 8.83 \%$; $P<0.01$ ). This inhibition profile was also due to the ability of these two compounds to reduce the relative fold change of neutrophils (\% inhibition: 3,5-diCQA, $2.5 \mathrm{mg} / \mathrm{kg}: 26.23 \pm 4.56 \%$ and $5 \mathrm{mg} / \mathrm{kg}: 41.99 \pm 5.54 \%$; 4,5-diCQA, $5 \mathrm{mg} / \mathrm{kg}: 43.55 \pm 8.12 \%$; $P<0.01)$. The two isomers also inhibited exudate protein concentration (\% inhibition: 3,5-diCQA, $2.5 \mathrm{mg} / \mathrm{kg}: 31.79 \pm$ $5.02 \%$ and $5 \mathrm{mg} / \mathrm{kg}: 36.96 \pm 4.74 \%$; 4,5 -diCQA, $5 \mathrm{mg} / \mathrm{kg}$ : $54.89 \pm 4.99 \% ; P<0.01$ ) (Table 1 ).

The aqueous and DCM fractions and the isomer 3,4diCQA did not inhibit leukocyte and exudate protein concentration (data not shown). In addition, CE, derived fractions, and isolated compounds did not inhibit mononuclear cells (data not shown).

The results revealed that CE $(50 \mathrm{mg} / \mathrm{kg})$, fractions (Hex, $10 \mathrm{mg} / \mathrm{kg} ; \mathrm{MeOH}, 10 \mathrm{mg} / \mathrm{kg}$; and EtOAc, $5 \mathrm{mg} / \mathrm{kg}$ ), and isolated compounds (3,5-diCQA, $2.5 \mathrm{mg} / \mathrm{kg}$ and 4,5-diCQA, $5 \mathrm{mg} / \mathrm{kg}$ ) were effective in inhibiting leukocyte numbers and exudate protein concentration. These doses were used in the next experiments.

3.3. Effect of CE, Fractions, and Isolated Compounds from $C$. pinnatifida on MPO and ADA Activities and $N O_{x}$ Levels. The MPO and ADA are important enzymes, which can be used as markers of activated neutrophils and mononuclear cells, respectively [38-40].

The CE, its derived fractions, and isolated compounds caused a significant decrease in MPO (\% inhibition: CE, $37.73 \pm 01.03 \%$; Hex, $31.69 \pm 2.16 \% ; \mathrm{MeOH}, 33.09 \pm 2.38 \%$; EtOAc, $30.25 \pm 0.39 \%$; 3,5-diCQA, $25.29 \pm 2.39 \%$; and 4,5diCQA, $20.10 \pm 2.93 \% ; P<0.01$ ) (Table 2) and ADA levels (\% inhibition: CE, 59.17 \pm 10.16 ; Hex, $44.48 \pm 6.72 \%$; $\mathrm{MeOH}, 71.59 \pm 5.78 \%$; EtOAc, $81.05 \pm 2.06 ; 3,5$-diCQA, $70.06 \pm 6.08 \% ;$ and 4,5-diCQA, $47.87 \pm 6.14 \% ; \quad P<0.01)$ (Table 2).

Moreover, CE, its derived fractions, and isolated compounds significantly decreased $\mathrm{NO}_{x}$ levels (\% inhibition: CE, $23.82 \pm 14.67 \%$; Hex, $40.37 \pm 3.49 \%$; MeOH, $26.68 \pm$ $3.60 \%$; EtOAc, $35.27 \pm 03.11 \%$; 3,5-diCQA, $33.60 \pm 3.44 \%$; and 4,5 -diCQA, $29.63 \pm 3.13 \% ; P<0.01$ ) (Table 2).

3.4. Effect of CE, Fractions, and Isolated Compounds from $C$. pinnatifida on TNF- $\alpha, I L-1 \beta$, and IL-17A Levels. Only CE, EtOAc fraction, and isolated compounds significantly decreased TNF- $\alpha$ levels (\% inhibition: CE, $54.50 \pm 4.11 \%$; EtOAc, $53.73 \pm 3.03 \%$; 3,5-diCQA, $70.15 \pm 11.15 \%$; and 4,5-diCQA, $56.45 \pm 6.76 \% ; P<0.05$ ) (Table 3).

The CE, fractions, and isolated compounds also decreased IL- $1 \beta$ levels (\% inhibition: CE, $53.59 \pm 1.15 \%$; Hex, 57.20 \pm 10.88\%; MeOH, 50.29 \pm 5.34\%; EtOAc, 29.81 $\pm 4.29 \%$; 3,5-diCQA, $79.94 \pm 5.29 \%$; and 4,5-diCQA, 76.33 $\pm 1.43 \% ; P<0.01$ ) (Table 3 ) and IL-17A levels (\% inhibition: CE, $55.87 \pm 5.88 \%$; Hex, 68.26 $\pm 23.11 \% ; \mathrm{MeOH}, 62.92 \pm$ 12.81\%; EtOAc, $42.99 \pm 8.39 \%$; 3.5-diCQA, $56.31 \pm 12.73 \%$; and 4.5-diCQA, $60.02 \pm 18.50 \% ; P<0.05$ ) (Table 3 ).
TABLE 2: Effects of CE, fractions, and isolated compounds obtained from C. pinnatifida leaves upon myeloperoxidase (MPO) and adenosine deaminase $(\mathrm{ADA})$ activities and nitrate/nitrite $\left(\mathrm{NO}_{x}\right)$ levels in a murine model of carrageenan-induced pleurisy.

\begin{tabular}{lccc}
\hline Groups $(\mathrm{mg} / \mathrm{kg})$ & $\mathrm{MPO}(\mathrm{mU} / \mathrm{mL})$ & $\mathrm{ADA}(\mathrm{U} / \mathrm{L})$ & $\mathrm{NO}_{x}(\mu \mathrm{M})$ \\
\hline $\mathrm{Sal}^{\mathrm{a}}$ & $64.47 \pm 1.63$ & $3.09 \pm 0.25$ & $8.48 \pm 0.22$ \\
$\mathrm{Cg}^{\mathrm{a}}$ & $114.2 \pm 16.54$ & $21.82 \pm 2.00$ & $18.36 \pm 1.34$ \\
$\mathrm{CE}(50)^{\mathrm{b}}$ & $71.09 \pm 1.81^{* *}$ & $8.91 \pm 2.22^{* *}$ & $13.98 \pm 2.69^{*}$ \\
$\mathrm{Hex}(25)^{\mathrm{b}}$ & $77.99 \pm 2.47^{* *}$ & $12.12 \pm 1.47^{* *}$ & $10.94 \pm 0.64^{* *}$ \\
$\mathrm{MeOH}(10)^{\mathrm{b}}$ & $76.39 \pm 2.72^{* *}$ & $6.20 \pm 1.26^{* *}$ & $13.45 \pm 0.66^{*}$ \\
EtOAc (5) & $79.63 \pm 0.46^{* *}$ & $4.14 \pm 0.45^{* *}$ & $11.88 \pm 0.57^{* *}$ \\
$3,5-\mathrm{diCQA}(2.5)^{\mathrm{b}}$ & $85.30 \pm 2.74^{* *}$ & $6.53 \pm 1.33^{* *}$ & $12.18 \pm 0.63^{* *}$ \\
$4,5-\mathrm{diCQA}(5)^{\mathrm{b}}$ & $91.23 \pm 3.35^{* *}$ & $11.38 \pm 1.34^{* *}$ & $12.91 \pm 0.58^{* *}$ \\
Dex $(0.5)^{\mathrm{b}}$ & $64.98 \pm 2.98^{* *}$ & $10.18 \pm 0.75^{* *}$ & $9.69 \pm 0.55^{* *}$ \\
Indo (5) & $67.44 \pm 4.81^{* *}$ & $10.49 \pm 0.99^{* *}$ & $11.54 \pm 0.40^{* *}$ \\
\hline
\end{tabular}

Crude extract (CE: $50 \mathrm{mg} / \mathrm{kg}$ ), hexane fraction (Hex: $25 \mathrm{mg} / \mathrm{kg}$ ), methanol fraction (MeOH: $10 \mathrm{mg} / \mathrm{kg}$ ), ethyl acetate fraction (EtOAc: $5 \mathrm{mg} / \mathrm{kg}$ ), 3,5di-O-E-caffeoylquinic acid (3,5-diCQA: $2.5 \mathrm{mg} / \mathrm{kg})$, and 4,5 -di-O-Ecaffeoylquinic acid (4,5-diCQA: $5 \mathrm{mg} / \mathrm{kg}$ ) obtained from C. pinnatifida leaves administered $0.5 \mathrm{~h}$ before pleurisy induction. Sal: negative control group, animals treated only with sterile saline $(0.95 \%)$; Cg: positive control group, animals treated only with carrageenan (1\%); Dex: animals treated with dexamethasone $(0.5 \mathrm{mg} / \mathrm{kg}) 0.5 \mathrm{~h}$ before pleurisy induction; Indo: animals treated with indomethacin $(5 \mathrm{mg} / \mathrm{kg}) \quad 0.5 \mathrm{~h}$ before pleurisy induction. ${ }^{\mathrm{a}}$ Administered by intrapleural route (i.pl.). ${ }^{\mathrm{b}}$ Administered by intraperitoneal route (i.p.). Each group represents the mean \pm SEM of six animals. ${ }^{*} P<0.05$ and ${ }^{* *} P<0.01$.

3.5. Effect of Isolated Compounds on the Phosphorylation of p65 NF- $\kappa B$ and $p 38 M A P K$. Our experiments showed that the isomers 3,5- and 4,5-diCQA were effective in inhibiting the phosphorylation of p $65 \mathrm{NF}-\kappa \mathrm{B}$ by $46.23 \pm 1.59 \%$ and $30.96 \pm 3.48 \%$, respectively $(P<0.05)$ and the phosphorylation of p38 MAPK by $50.00 \pm 1.43 \%$ and $38.75 \pm 2.83 \%$, respectively $(P<0.01)$ (Figure 2$)$.

\section{Discussion}

Our study demonstrated important anti-inflammatory activities of C. pinnatifida. This herb caused a significant decrease in leukocyte numbers and exudation. These effects appear to be related to the decrease in MPO and ADA activities and also production of mediators involved in the inflammatory response (NO and proinflammatory cytokines (TNF- $\alpha$, IL- $1 \beta$, and IL-17A)).

Our results are consistent with other studies for this genre, such as studies by Gómez and Gil [12] and Guevara et al. [41] who demonstrated that C. prunifolia inhibited both 12-O-tetradecanoylphorbol-13-acetate-induced ear edema and Cg-induced paw edema in mice. Studies have also demonstrated anti-inflammatory effects of the aqueous extract of C. zacatechichi that decreased neutrophil migration into the Cg-induced peritoneal inflammation in rats [42] and antiinflammatory and antinociceptive effects of the $\mathrm{MeOH}$ extract of C. zacatechichi that inhibited Cg-induced paw edema and acetic acid-induced abdominal writhes in mice 
TABLE 3: Effects of CE, fractions, and isolated compounds of $C$. pinnatifida upon tumor necrosis factor-alpha (TNF- $\alpha$ ), interleukin- $1 \beta$ (IL-1 $\beta$ ), and interleukin-17A (IL-17A) in a murine model of carrageenan-induced pleurisy.

\begin{tabular}{|c|c|c|c|}
\hline Groups (mg/kg) & TNF- $\alpha(\mathrm{pg} / \mathrm{mL})$ & $\mathrm{IL}-1 \beta(\mathrm{pg} / \mathrm{mL})$ & IL-17A (pg/mL) \\
\hline$\overline{\mathrm{Sal}^{\mathrm{a}}}$ & $85.05 \pm 8.35$ & $115.1 \pm 21.72$ & $98.90 \pm 5.62$ \\
\hline $\mathrm{Cg}^{\mathrm{a}}$ & $991.3 \pm 2.27$ & $1545.00 \pm 170.50$ & $337.00 \pm 1.14$ \\
\hline $\mathrm{CE}(50)^{\mathrm{b}}$ & $451.10 \pm 40.76^{* *}$ & $717.10 \pm 17.78^{* *}$ & $148.70 \pm 19.85^{* *}$ \\
\hline $\operatorname{Hex}(25)^{\mathrm{b}}$ & $895.50 \pm 50.11$ & $661.30 \pm 168.10^{* *}$ & $124.40 \pm 69.29^{* *}$ \\
\hline $\mathrm{MeOH}(10)^{\mathrm{b}}$ & $809.00 \pm 110.10$ & $768.00 \pm 82.63^{* *}$ & $125.00 \pm 43.16^{* *}$ \\
\hline EtOAc $(5)^{\mathrm{b}}$ & $458.60 \pm 30.16^{* *}$ & $1085.00 \pm 66.39^{* *}$ & $192.10 \pm 28.31^{*}$ \\
\hline 3,5-diCQA $(2.5)^{\mathrm{b}}$ & $296.00 \pm 110.60^{* *}$ & $310.00 \pm 81.82^{* *}$ & $147.20 \pm 42.91^{* *}$ \\
\hline $4,5-\operatorname{diCQA}(5)^{\mathrm{b}}$ & $431.7 \pm 67.08^{* *}$ & $365.80 \pm 22.10^{* *}$ & $172.40 \pm 34.85^{* *}$ \\
\hline $\operatorname{Dex}(0.5)^{\mathrm{b}}$ & $371.00 \pm 58.24^{* *}$ & $243.3 \pm 6.00^{* *}$ & $143.80 \pm 42.47^{* *}$ \\
\hline Indo $(5)^{\mathrm{b}}$ & $415.80 \pm 64.96^{* *}$ & $467.8 \pm 117.50^{* *}$ & $124.10 \pm 40.46^{* *}$ \\
\hline
\end{tabular}

Crude extract (CE: $50 \mathrm{mg} / \mathrm{kg}$ ), hexane fraction (Hex: $25 \mathrm{mg} / \mathrm{kg}$ ), methanol fraction (MeOH: $10 \mathrm{mg} / \mathrm{kg}$ ), ethyl acetate fraction (EtOAc: $5 \mathrm{mg} / \mathrm{kg}$ ), 3,5-di-O-Ecaffeoylquinic acid (3,5-diCQA: $2.5 \mathrm{mg} / \mathrm{kg}$ ), and 4,5-di-O-E-caffeoylquinic acid (4,5-diCQA: $5 \mathrm{mg} / \mathrm{kg}$ ) obtained from C. pinnatifida leaves administered $0.5 \mathrm{~h}$ before pleurisy induction. Sal: negative control group, animals treated only with sterile saline (0.95\%); Cg: positive control group, animals treated only with carrageenan (1\%); Dex: animals treated with dexamethasone $(0.5 \mathrm{mg} / \mathrm{kg}) 0.5 \mathrm{~h}$ before pleurisy induction; Indo: animals treated with indomethacin $(5 \mathrm{mg} / \mathrm{kg})$ $0.5 \mathrm{~h}$ before pleurisy induction. ${ }^{\mathrm{a}} \mathrm{Administered} \mathrm{by} \mathrm{intra-pleural} \mathrm{route} \mathrm{(i.pl.).}{ }^{\mathrm{b}}$ Administered by intra-peritoneal route (i.p.). Each group represents the mean \pm SEM of six animals. ${ }^{*} P<0.05$ and ${ }^{* *} P<0.01$.

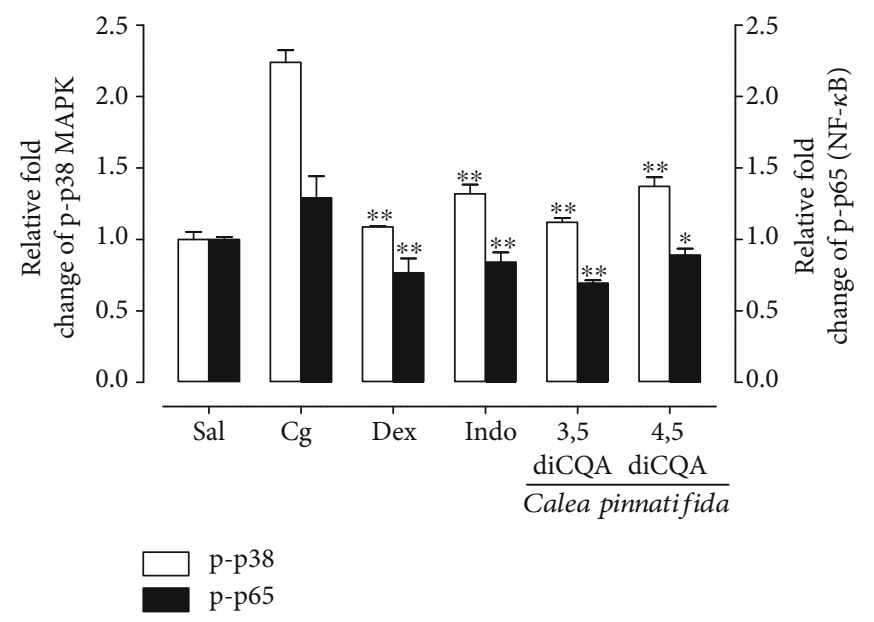

FIGURE 2: Effects of isolated compounds obtained from Calea pinnatifida leaves on p65 (p-p65 NF- $\kappa$ B) and p38 (p-p38 MAPK) phosphorylation. 3,5-di-O-E-caffeoylquinic acid (3,5-diCQA: $2.5 \mathrm{mg} / \mathrm{kg}$ ) and 4,5-di-O-E-caffeoylquinic acid (4,5-diCQA: 5 mg/kg) administered $0.5 \mathrm{~h}$ before pleurisy induction. Sal: negative control group, animals treated only with sterile saline; Cg: positive control group, animals treated only with carrageenan (1\%); Dex: animals treated with dexamethasone $(0.5 \mathrm{mg} / \mathrm{kg}) 0.5 \mathrm{~h}$ before pleurisy induction; Indo: animals treated with indomethacin $(5 \mathrm{mg} / \mathrm{kg}) 0.5 \mathrm{~h}$ before pleurisy induction. Bars indicate the mean \pm SEM of six animals. ${ }^{*} P<0.05$ and ${ }^{* *} P<0.01$.

and rats, respectively [16]. Moreover, in vitro studies showed that the $\mathrm{MeOH}$ extract of $C$. zacatechichi also inhibited prostaglandin E2 production in activated macrophages induced by lipopolysaccharides (LPS) in the peritoneal cavity of rats [42].

The CE, derived fractions, and isolated compounds obtained from C. pinnatifida leaves inhibited leukocytes and exudate protein concentration. The EtOAc fraction showed greater inhibition of these inflammatory parameters because a lower dose of this fraction $(5 \mathrm{mg} / \mathrm{kg})$ decreased all the studied inflammatory parameters compared with that of $\mathrm{CE}$ and $\mathrm{Hex}$ and $\mathrm{MeOH}$ fractions, which inhibited the same inflammation at higher doses of 50, 25, and $10 \mathrm{mg} / \mathrm{kg}$, respectively. Considering the isolated compounds, 3,5-diCQA showed a more potent anti-inflammatory effect than 4,5diCQA because a lower dose of 3,5-diCQA $(2.5 \mathrm{mg} / \mathrm{kg})$ inhibited the inflammation parameters compared with that of $4,5 \mathrm{diCQA}$ ( $5 \mathrm{mg} / \mathrm{kg}$ ).

The inhibitory effect of neutrophils and MPO and ADA are correlated with the inhibition of activated cells because MPO is abundantly expressed in neutrophils and is directly related to the phagocytic activity of these cells [43]. Furthermore, ADA activity is important in the regulation of extracellular adenosine concentrations and consequently 
in stimulating receptors mainly involved in modulating the inflammatory response [44]. In pulmonary tissue and neutrophils, $\mathrm{A}_{2 \mathrm{~A}}$ receptors mediate most of the anti-inflammatory effects of adenosine, and the expression of this receptor is increased in an inflamed lung [45-47].

The CE, derived fractions, and isolated compounds also inhibited the exudation process. This effect is associated with the ability of the plant material to decrease $\mathrm{NO}_{x}$ concentrations. NO has several roles in immune responses, including infection control, regulation of signaling cascades, transcription factors, rolling and migration of leukocytes, and cytokine production, and control of vascular responses [48]. In vitro studies corroborate with our results because the authors showed the inhibitory effect of 3,5-diCQA and 4,5-diCQA on NO production in LPS-induced RAW 264.7 cells, and this effect was related to the inhibition of inducible NO $[25,49]$.

The involvement of TNF- $\alpha$ and IL- $1 \beta$ in Cg-induced inflammation in mice has already been reported [50]. Cg activates toll-like receptor 4 and leads to the transcription of these cytokines [51]. TNF- $\alpha$ and IL- $1 \beta$ are important proinflammatory cytokines, mainly secreted by neutrophils and macrophages that play a central role in the onset and progression of the inflammatory responses [52]. The beneficial effects of TNF- $\alpha$ inhibition was demonstrated in the murine models of lung inflammation [53, 54]. Furthermore, studies showed that there is an increase in IL- $1 \beta$ concentrations in patients with COPD and neutrophilic asthma and also in the experimental models of smoke-induced COPD in mice $[3,55-57]$. In our experiments, $C$. pinnatifida was effective in inhibiting TNF- $\alpha$ and IL- $1 \beta$. Consistent with our findings, recent results demonstrated the ability of caffeoylquinic acids to inhibit TNF- $\alpha$ expression in LPS-stimulated RAW264.7 cells $[24,49]$ and decrease the release of IL- $1 \beta$ by TNF- $\alpha$ stimulated human keratinocytes [58].

The CE, derived fractions, and compounds isolated from C. pinnatifida were also effective in decreasing IL-17A concentrations in pleural fluid after Cg-induced inflammation. IL-17A is another cytokine that has been gaining importance in the development of inflammatory disease [59]. This cytokine has multiple functions, such as stimulation of inflammatory cells, mediators' secretion, and neutrophil recruitment, which occur in synergism with TNF- $\alpha$ in the activation of endothelial cells [60]. The increased level of IL-17A or its mRNA were detected in sputum [61], bronchial tissues $[62]$, and serum $[63,64]$ of patients with asthma. In addition, neutrophils in the airways of asthmatic patients appear to be related to the increased IL-17A expression [61].

It is well known that NF- $\kappa \mathrm{B}$ and MAPK pathways are involved in the inflammatory response. NF- $\kappa \mathrm{B}$ pathway increases the expression of many proinflammatory genes, including cytokines, chemokines, and adhesion molecules [65]. p38 MAPK plays a key role in the inflammatory responses via proinflammatory cytokine activation and production, NO synthase induction, cell proliferation, cell differentiation, and apoptosis induction [66].

To try understanding the anti-inflammatory mechanism of action of $C$. pinnatifida, we propose to analyzed the effect of the isolated compounds (3,5-diCQA and 4,5-diCQA) upon NF- $\kappa$ B and MAPK pathways. Our results revealed that both isomers of caffeoylquinic acid inhibited the phosphorylation of $\mathrm{p} 65 \mathrm{NF}-\kappa \mathrm{B}$ and $\mathrm{p} 38 \mathrm{MAPK}$. These findings are consistent with those of our previous study, which showed the inhibitory effect of a mixture of diCQA isomers on p65 NF$\kappa \mathrm{B}$ phosphorylation [27]. Furthermore, recent studies have shown that 3,5-diCQA and 4,5-diCQA inhibit p65 nuclear translocation in LPS-induced RAW 264.7 macrophages by preventing the degradation of $\mathrm{I} \kappa \mathrm{B} \alpha$, an important inhibitory protein in the p65 NF- $\kappa$ B pathway $[24,25]$. Similar to our findings, a study assessing the effect of a polyphenol mixture isolated from Lonicera japonica Thunb. containing diCQAs showed the ability of diCQAs to inhibit the phosphorylation of p38 MAPK in LPS-stimulated RAW 246.7 macrophages [67]. Furthermore, inhibition of this pathway by diCQAs present in a propolis $\mathrm{MeOH}$ extract was observed in another in vitro study using LPS-stimulated RAW 246.7 macrophages, and these compounds were effective in inhibiting p38 MAPK phosphorylation [68].

\section{Conclusion}

In summary, we demonstrate for the first time the antiinflammatory effects of C. pinnatifida in an in vivo model of lung inflammation. The CE, derived fractions, and isolated compounds showed significant anti-inflammatory properties by inhibiting leukocytes and exudation and decreasing the activities of ADA and MPO and the concentrations of important proinflammatory mediators, such as NO, TNF- $\alpha$, IL- $1 \beta$, and IL-17A. These effects are related to the ability of 3,5diCQA and 4,5-diCQA to act on p65 NF- $\kappa$ B and p38 MAPK phosphorylation, two important intracellular pathways in the progression and maintenance of inflammatory processes.

\section{Abbreviations}

ADA: Adenosine deaminase

CE: $\quad$ Crude extract

Cg: Carrageenan

DCM: Dichloromethane

Dex: Dexamethasone

EtOAc: Ethyl acetate

Indo: Indomethacin

IL-1 $\beta$ : Interleukin-1-beta

IL-17A: Interleukin-17A

ELISA: Enzyme-linked immunosorbent assay

Hex: Hexane

MAPK: Mitogen-activated protein kinases

MeOH: Methanol

MPO: Myeloperoxidase

NF- $\kappa$ B: Nuclear transcription factor kappa B

NO: $\quad$ Nitric oxide

NOx: Nitric oxide metabolites

TNF- $\alpha$ : Tumor necrosis factor-alpha.

\section{Data Availability}

No data were used to support this study. 


\section{Conflicts of Interest}

The authors declare that they have no conflict of interest.

\section{Authors' Contributions}

E.M. Dalmarco and T.S. Fröde conceived and designed the study. B.M. de Campos Facchin, J. S. da Rosa, Y. J. K. Moon, A. B. Gobbo Luz, T.C. de Lima, R. Casoti, and M.W. Biavatti performed the experiments. J.S. Da Rosa, E.M. Dalmarco, T.S. Fröde, and M.W. Biavatti analyzed the data. J.S. Da Rosa and T.S. Fröde drafted the manuscript. All authors read and approved the final manuscript.

\section{Acknowledgments}

This work was supported by the Conselho Nacional de Desenvolvimento Científico e Tecnológico (CNPq, Brazil) and Coordenação de Aperfeiçoamento de Pessoal de Nível Superior (CAPES, Brazil).

\section{References}

[1] C. Nathan and A. Ding, "Nonresolving inflammation," Cell, vol. 140, no. 6, pp. 871-882, 2010.

[2] W. W. Busse and R. F. Lemanske Jr., "Asthma," The New England Journal of Medicine, vol. 344, no. 5, pp. 350-362, 2001.

[3] J. L. Simpson, S. Phipps, K. J. Baines, K. M. Oreo, L. Gunawardhana, and P. G. Gibson, "Elevated expression of the NLRP3 inflammasome in neutrophilic asthma," The European Respiratory Journal, vol. 43, no. 4, pp. 1067-1076, 2014.

[4] J. L. Simpson, R. Scott, M. J. Boyle, and P. G. Gibson, "Inflammatory subtypes in asthma: assessment and identification using induced sputum," Respirology, vol. 11, no. 1, pp. 54-61, 2006.

[5] M. B. Sukkar, L. G. Wood, M. Tooze et al., "Soluble RAGE is deficient in neutrophilic Asthma and COPD," European Respiratory Journal, vol. 39, no. 3, pp. 721-729, 2012.

[6] T. S. F. Saleh, J. B. Calixto, and Y. S. Medeiros, "Anti-inflammatory effects of theophylline, cromolyn and salbutamol in a murine model of pleurisy," British Journal of Pharmacology, vol. 118, no. 3, pp. 811-819, 1996.

[7] A. G. Atanasov, B. Waltenberger, E.-M. Pferschy-Wenzig et al., "Discovery and resupply of pharmacologically active plant-derived natural products: a review," Biotechnology Advances, vol. 33, no. 8, pp. 1582-1614, 2015.

[8] J. B. Calixto and J. M. Siqueira Jr., "The drug development in Brazil: challenges," Gaz Médica Da Bahia, vol. 78, pp. 98106, 2008.

[9] G. P. Cosenza, N. S. Somavilla, C. W. Fagg, and M. G. L. Brandão, "Bitter plants used as substitute of Cinchona spp. (quina) in Brazilian traditional medicine," Journal of Ethnopharmacology, vol. 149, no. 3, pp. 790-796, 2013.

[10] H. de Falcão, I. Lima, V. L. dos Santos et al., "Review of the plants with anti-inflammatory activity studied in Brazil," Revista Brasileira de Farmacognosia, vol. 15, no. 4, pp. 381391, 2005.

[11] N. Roque and V. C. Carvalho, "Estudos taxonômicos do gênero Calea (Asteraceae, Neurolaeneae) no estado da Bahia, Brasil," Rodriguésia, vol. 62, no. 3, pp. 547-561, 2011.
[12] M. Gómez and J. F. Gil, "Topical anti-inflammatory activity of Calea prunifolia HBK (Asteraceae) in the TPA model of mouse ear inflammation," Journal of the Brazilian Chemical Society, vol. 22, no. 12, pp. 2391-2395, 2011.

[13] M. F. Guerrero, P. Puebla, R. Carrón, M. L. Martín, L. Arteaga, and L. S. Román, "Assessment of the antihypertensive and vasodilator effects of ethanolic extracts of some Colombian medicinal plants," Journal of Ethnopharmacology, vol. 80, no. 1, pp. 37-42, 2002.

[14] I. Köhler, K. Jenett-Siems, K. Siems et al., "In vitro antiplasmodial investigation of medicinal plants from El Salvador $\$$," Zeitschrift für Naturforschung C, vol. 57, no. 3-4, pp. 277281, 2002.

[15] R. Román Ramos, F. Alarcón-Aguilar, A. Lara-Lemus, and J. L. Flores-Saenz, "Hypoglycemic effect of plants used in Mexico as antidiabetics," Archives of Medical Research, vol. 23, no. 1, pp. 59-64, 1992.

[16] D. Segura-Cobos, H. Venegas-Flores, L. Baiza-Gutman, and B. Vázquez-Cruz, "Antinociceptive and anti-inflammatory effects of the methanol extract of Calea zacatechichi leaves and its fractions," Pharmacology, vol. 2, pp. 1100-1110, 2010.

[17] H. Wu, F. Fronczek, C. Burandt Jr., and J. Zjawiony, "Antileishmanial Germacranolides from Calea zacatechichi," Planta Medica, vol. 77, no. 7, pp. 749-753, 2011.

[18] J. F. Pruski and L. E. Urbatsch, "Five new species of Calea (Compositae: Heliantheae) from Planaltine Brazil," Brittonia, vol. 40, no. 4, pp. 341-356, 1988.

[19] Marchetti, Silva, Santos et al., "The anticancer activity of dichloromethane crude extract obtained from Calea pinnatifida," Journal of Experimental Pharmacology, vol. 4, pp. 157$162,2012$.

[20] T. C. Lima, A. D. C. Santos, D. T. M. Costa et al., "Chromenes from leaves of Calea pinnatifida and evaluation of their leishmanicidal activity," Revista Brasileira de Farmacognosia, vol. 25, no. 1, pp. 7-10, 2015.

[21] Z. S. Ferreira, N. F. Roque, R. O. Gottlieb, and F. Oliveira, "Chemical study on Calea pinnatifida," Cien Cult, vol. 32, pp. 83-85, 1980.

[22] E. T. M. Kato, M. K. Akisue, F. J. A. Matos, A. A. Craveiro, and J. M. Alecar, "Constituents of Calea pinnatifida," Fitoterapia, vol. 65, p. 377, 1994.

[23] I. M. Adcock and P. J. Barnes, "Molecular mechanisms of corticosteroid resistance," Chest, vol. 134, no. 2, pp. 394-401, 2008.

[24] X. Chen, J. Miao, H. Wang et al., "The anti-inflammatory activities of Ainsliaea fragrans Champ. extract and its components in lipopolysaccharide-stimulated RAW264.7 macrophages through inhibition of NF- $\kappa \mathrm{B}$ pathway," Journal of Ethnopharmacology, vol. 170, pp. 72-80, 2015.

[25] S. Puangpraphant, M. A. Berhow, K. Vermillion, G. Potts, and E. Gonzalez de Mejia, "Dicaffeoylquinic acids in Yerba mate (Ilex paraguariensis St. Hilaire) inhibit NF- $\kappa \mathrm{B}$ nucleus translocation in macrophages and induce apoptosis by activating caspases- 8 and -3 in human colon cancer cells," Molecular Nutrition \& Food Research, vol. 55, no. 10, pp. 1509-1522, 2011.

[26] F. L. M. Ricciardolo, L. Petecchia, V. Sorbello et al., "Bradykinin b2 receptor expression in the bronchial mucosa of allergic asthmatics: the role of NF-kB," Clinical \& Experimental Allergy, vol. 46, no. 3, pp. 428-438, 2016. 
[27] R. R. De Souza, L. C. Bretanha, E. M. Dalmarco, M. G. Pizzolatti, and T. S. Fröde, "Modulatory effect of Senecio brasiliensis (Spreng) Less. in a murine model of inflammation induced by carrageenan into the pleural cavity," Journal of Ethnopharmacology, vol. 168, pp. 373-379, 2015.

[28] T. C. Lima, R. d. J. Souza, M. H. d. Moraes, M. Steindel, and M. W. Biavatti, "A new furanoheliangolide sesquiterpene lactone from Calea pinnatifida (R. Br.) Less. (Asteraceae) and evaluation of its trypanocidal and leishmanicidal activities," Journal of the Brazilian Chemical Society, vol. 28, pp. 367375, 2017.

[29] G. Giusti and B. Galanti, "Adenosine deaminase: colorimetric method," in Methods of Enzymatic Analysis, H. U. Bergmeyer, Ed., vol. 4, Verlac Chemie, Weinheim, 3rd edition, 1984.

[30] T. S. Rao, J. L. Currie, A. F. Shaffer, and P. C. Isakson, "Comparative evaluation of arachidonic acid (AA)- and tetradecanoylphorbol acetate (TPA)-induced dermal inflammation," Inflammation, vol. 17, no. 6, pp. 723-741, 1993.

[31] L. C. Green, D. A. Wagner, J. Glogowski, P. L. Skipper, J. S. Wishnok, and S. R. Tannenbaum, "Analysis of nitrate, nitrite, and $\left[{ }^{15} \mathrm{~N}\right]$ nitrate in biological fluids," Analytical Biochemistry, vol. 126, no. 1, pp. 131-138, 1982.

[32] O. H. Lowry and R. J. Randall, "Lowry's handbook of right-toknow emergency planning : by G.G. Lowry and R.C. Lowry, Lewis Publishers, Chelsea, MI, 1988, ISBN 0-87371-112-2, 421 pp., \$ 85.00.," vol. 30, no. 3, pp. 361-362, 1951.

[33] M. N. Clifford, K. L. Johnston, S. Knight, and N. Kuhnert, "Hierarchical scheme for LC-MSn identification of chlorogenic acids," Journal of Agricultural and Food Chemistry, vol. 51, no. 10, pp. 2900-2911, 2003.

[34] M. N. Clifford, J. Kirkpatrick, N. Kuhnert, H. Roozendaal, and P. R. Salgado, "LC-MS ${ }^{n}$ analysis of the cis isomers of chlorogenic acids," Food Chemistry, vol. 106, no. 1, pp. 379-385, 2008.

[35] M. N. Clifford, S. Knight, and N. Kuhnert, "Discriminating between the six isomers of dicaffeoylquinic acid by LC-MSn," Journal of Agricultural and Food Chemistry, vol. 53, no. 10, pp. 3821-3832, 2005.

[36] M. N. Clifford, W. Wu, J. Kirkpatrick, and N. Kuhnert, "Profiling the chlorogenic acids and other caffeic acid derivatives of herbal chrysanthemum by LC-MS ${ }^{\mathrm{n}}$," Journal of Agricultural and Food Chemistry, vol. 55, no. 3, pp. 929-936, 2007.

[37] T. C. Lima, R. J. Souza, A. D. C. Santos et al., "Evaluation of leishmanicidal and trypanocidal activities of phenolic compounds from Calea uniflora Less," Natural Product Research, vol. 30, no. 5, pp. 551-557, 2015.

[38] T. S. Fröde and Y. S. Medeiros, "Myeloperoxidase and adenosine-deaminase levels in the pleural fluid leakage induced by carrageenan in the mouse model of pleurisy," Mediators of Inflammation, vol. 10, no. 4, pp. 223-227, 2001.

[39] R. Krenke and P. Korczyński, "Use of pleural fluid levels of adenosine deaminase and interferon gamma in the diagnosis of tuberculous pleuritis," Current Opinion in Pulmonary Medicine, vol. 16, no. 4, pp. 367-375, 2010.

[40] A. L. MacDowell and S. P. Peters, "Neutrophils in asthma," Journal of Investigational Allergology \& Clinical Immunology, vol. 7, no. 6, pp. 464-468, 2007.

[41] M. C. G. Guevara, L. F. O. Giraldo, and J. R. Velandia, "Actividad antiinflamatoria de extractos y fracciones de Myrcianthes leucoxila, Calea prunifolia, Curatella americana Y Physalis peruviana en los modelos edema auticular por TPA, edema plantar por carragenina y artritis inducida por colágeno," Bios, vol. 10, pp. 9-18, 2011.

[42] H. Venegas-Flores, D. Segura-Cobos, and B. Vázquez-cruz, "Antiinflammatory activity of the aqueous extract of Calea zacatechichi," Proceedings of the Western Pharmacology Society, vol. 45, pp. 110-111, 2002.

[43] C. Nussbaum, A. Klinke, M. Adam, S. Baldus, and M. Sperandio, "Myeloperoxidase: a leukocyte-derived protagonist of Inflammation and Cardiovascular Disease," Antioxidants \& Redox Signaling, vol. 18, no. 6, pp. 692-713, 2013.

[44] L. Antonioli, R. Colucci, C. la Motta et al., "Adenosine deaminase in the modulation of immune system and its potential as a novel target for treatment of inflammatory disorders," Current Drug Targets, vol. 13, no. 6, pp. 842-862, 2012.

[45] K. E. Barletta, K. Ley, and B. Mehrad, "Regulation of neutrophil function by adenosine," Arteriosclerosis, Thrombosis, and Vascular Biology, vol. 32, no. 4, pp. 856-864, 2012.

[46] F. M. Konrad, G. Neudeck, I. Vollmer, K. C. Ngamsri, M. Thiel, and J. Reutershan, "Protective effects of pentoxifylline in pulmonary inflammation are adenosine receptor A2A dependent," The FASEB Journal, vol. 27, no. 9, pp. 35243535, 2013.

[47] J. Reutershan, R. E. Cagnina, D. Chang, J. Linden, and K. Ley, "Therapeutic anti-inflammatory effects of myeloid cell adenosine receptor A2a stimulation in Lipopolysaccharide-induced lung Injury," Journal of Immunology, vol. 179, no. 2, pp. 1254-1263, 2007.

[48] K. Mao, S. Chen, M. Chen et al., "Nitric oxide suppresses NLRP3 inflammasome activation and protects against LPSinduced septic shock," Cell Research, vol. 23, no. 2, pp. 201212, 2013.

[49] S. Hong, T. Joo, and J.-W. Jhoo, "Antioxidant and antiinflammatory activities of 3,5-dicaffeoylquinic acid isolated from Ligularia fischeri leaves," Food Science and Biotechnology, vol. 24, no. 1, pp. 257-263, 2015.

[50] T. S. Fröde, G. E. P. Souza, and J. B. Calixto, “The modulatory role played by TNF- $\alpha$ and IL- $1 \beta$ in the inflammatory responses induced by carrageenan in the mouse model of pleurisy," Cytokine, vol. 13, no. 3, pp. 162-168, 2001.

[51] C. Reynolds, "Toll-like receptors 2 and 4 and innate immunity in neutrophilic asthma and idiopathic bronchiectasis," Thorax, vol. 62, p. 279, 2007.

[52] M. D. Turner, B. Nedjai, T. Hurst, and D. J. Pennington, "Cytokines and chemokines: At the crossroads of cell signalling and inflammatory disease," Biochimica et Biophysica Acta (BBA) - Molecular Cell Research, vol. 1843, no. 11, pp. 25632582, 2014.

[53] S. K. Babu, S. M. Puddicombe, H. H. Arshad et al., "Tumor necrosis factor alpha (TNF- $\alpha$ ) autoregulates its expression and induces adhesion molecule expression in asthma," Clinical Immunology, vol. 140, no. 1, pp. 18-25, 2011.

[54] F. Catal, E. Mete, C. Tayman, E. Topal, A. Albayrak, and H. Sert, "A human monoclonal anti-TNF alpha antibody (adalimumab) reduces airway inflammation and ameliorates lung histology in a murine model of acute asthma," Allergologia et Immunopathologia, vol. 43, no. 1, pp. 14-18, 2015.

[55] K. J. Baines, J. L. Simpson, L. G. Wood, R. J. Scott, and P. G. Gibson, "Transcriptional phenotypes of asthma defined by gene expression profiling of induced sputum samples," Journal of Allergy and Clinical Immunology, vol. 127, no. 1, pp. 153160.e9, 2011. 
[56] E. L. Beckett, R. L. Stevens, A. G. Jarnicki et al., "A new shortterm mouse model of chronic obstructive pulmonary disease identifies a role for mast cell tryptase in pathogenesis," The Journal of Allergy and Clinical Immunology, vol. 131, no. 3, pp. 752-762.e7, 2013.

[57] A. Churg, S. Zhou, X. Wang, R. Wang, and J. L. Wright, “The role of interleukin-1 $\beta$ in murine cigarette smoke-induced emphysema and small airway remodeling," American Journal of Respiratory Cell and Molecular Biology, vol. 40, no. 4, pp. 482-490, 2009.

[58] C. S. Lee, S. A. Lee, Y. J. Kim, S. J. Seo, and M. W. Lee, "3,4,5Tricaffeoylquinic acid inhibits tumor necrosis factor- $\alpha$-stimulated production of inflammatory mediators in keratinocytes via suppression of Akt- and NF- $\kappa$ B-pathways," International Immunopharmacology, vol. 11, no. 11, pp. 1715-1723, 2011.

[59] P. Miossec and J. K. Kolls, "Targeting IL-17 and $\mathrm{T}_{\mathrm{H}} 17$ cells in chronic inflammation," Nature Reviews. Drug Discovery, vol. 11, no. 10, pp. 763-776, 2012.

[60] G. K. Griffin, G. Newton, M. L. Tarrio et al., "IL-17 and TNF- $\alpha$ sustain neutrophil recruitment during inflammation through synergistic effects on endothelial activation," Journal of Immunology, vol. 188, no. 12, pp. 6287-6299, 2012.

[61] D. Bullens, E. Truyen, L. Coteur et al., "IL-17 mRNA in sputum of asthmatic patients: linking T cell driven inflammation and granulocytic influx?," Respiratory Research, vol. 7, no. 1, article 135, 2006.

[62] A. Vazquez-Tello, A. Semlali, J. Chakir et al., "Induction of glucocorticoid receptor- $\beta$ expression in epithelial cells of asthmatic airways by T-helper type 17 cytokines," Clinical and Experimental Allergy, vol. 40, no. 9, pp. 1312-1322, 2010.

[63] I. Agache, C. Ciobanu, C. Agache, and M. Anghel, "Increased serum IL-17 is an independent risk factor for severe asthma," Respiratory Medicine, vol. 104, no. 8, pp. 1131-1137, 2010.

[64] G. D. Albano, C. Di Sano, A. Bonanno et al., "Th17 immunity in children with allergic asthma and rhinitis: a pharmacological approach," PLoS One, vol. 8, no. 4, article e58892, 2013.

[65] T. Lawrence, "The nuclear factor NF- $\kappa$ B pathway in inflammation," Cold Spring Harbor Perspectives in Biology, vol. 1, no. 6, article a001651, 2009.

[66] Y. Yang, S. C. Kim, T. Yu et al., "Functional Roles of p38 Mitogen-Activated Protein Kinase in Macrophage- Mediated Inflammatory Responses," Mediators of Inflammation, vol. 2014, Article ID 352371, 13 pages, 2014.

[67] K.-I. Park, S.-R. Kang, H.-S. Park et al., "Regulation of Proinflammatory Mediators via NF- $\kappa$ B and p38 MAPK- Dependent Mechanisms in RAW 264.7 Macrophages by Polyphenol Components Isolated from Korea Lonicera japonica THUNB," Evidence-Based Complementary and Alternative Medicine, vol. 2012, Article ID 828521, 10 pages, 2012.

[68] M. C. Búfalo, I. Ferreira, G. Costa et al., "Propolis and its constituent caffeic acid suppress LPS-stimulated pro- inflammatory response by blocking NF- $\kappa \mathrm{B}$ and MAPK activation in macrophages," Journal of Ethnopharmacology, vol. 149, no. 1, pp. 84-92, 2013. 